\title{
The impact of the partial replacement of sodium chloride in the development of starter cultures during Italian salami production
}

\author{
Impacto da substituição parcial do cloreto de sódio no desenvolvimento da cultura \\ starter durante a produção do salame tipo italiano
}

\author{
Claudia Fieira ${ }^{1}$, João Francisco Marchi' ${ }^{1}$, Daiana Marafão ${ }^{1}$, Alexandre da Trindade Alfaro"* \\ ${ }^{1}$ Universidade Tecnológica Federal do Paraná (UTFPR), Laboratório de Tecnologia de Alimentos, Francisco Beltrão/PR - Brasil
}

\section{*Corresponding Author}

Alexandre da Trindade Alfaro, Universidade Tecnológica Federal do Paraná (UTFPR), Laboratório de Tecnologia de Alimentos, Linha Santa Bárbara, s/n, Caixa Postal: 135, CEP: 85601-970, Francisco Beltrão/PR - Brazil, e-mail: alexandre@utfpr.edu.br

Cite as: The impact of the partial replacement of sodium chloride in the development of starter cultures during Italian salami production. Braz. J. Food Technol., v. 21, e2015036, 2018.

Received: May 27, 2015; Accepted: Nov. 08, 2017

\section{Abstract}

Italian salami is a cured meat with high sodium contents which is easy, fast and convenient to consume. Starter cultures are used to improve its sensory characteristics and refine its technological manufacturing process. The goal of this study was to reduce the sodium content in Italian salami through the partial replacement of sodium chloride by potassium chloride, magnesium chloride and calcium chloride, and evaluate the viability of the Lactobacillus sp. and Staphylococcus sp. cells found in the starter culture. Four formulations were elaborated: one with, and one without the starter culture, but both with the addition of sodium chloride; and two with the partial replacement of $60 \%$ of the sodium chloride: the first with $\mathrm{KCl}$, and the other with a mixture of $\mathrm{KCl}, \mathrm{MgCl}_{2}$ and $\mathrm{CaCl}_{2}$. Physicochemical and microbiological evaluations were carried out to monitor the ripening and the quality of the final product. The partial replacement of $\mathrm{NaCl}$ by other salts $\left(\mathrm{MgCl}_{2}, \mathrm{CaCl}_{2}, \mathrm{KCl}\right)$ did not interfere in the growth of the starter culture in the Italian salami, neither did it affect the majority of the physicochemical parameters of the Italian salami nor the microbiological quality of the final product.

Keywords: Cured sausages; Sodium content; Staphylococcus; Lactobacillus.

\section{Resumo}

O salame tipo italiano, um embutido cárneo processado, de consumo fácil, prático e rápido, apresenta elevados teores de sódio. Para o seu processamento, utilizam-se culturas starters que melhoram suas características sensoriais e facilitam o processo tecnológico de fabricação. O objetivo deste trabalho foi reduzir o teor de sódio em salame tipo italiano, através da sua substituição parcial por cloreto de potássio, cloreto de magnésio e cloreto de cálcio, além de verificar a viabilidade das células de Lactobacillus sp. e Staphylococcus sp., presentes na cultura starter. Foram elaboradas quatro formulações: uma formulação sem e outra com cultura starter, ambas somente com adição de cloreto de sódio; outras duas, com substituição parcial de $60 \%$ do cloreto de sódio: uma por $\mathrm{KCl}$ e outra por mistura de $\mathrm{KCl}, \mathrm{MgCl}_{2}, \mathrm{CaCl}_{2}$. Foram realizadas avaliações físico-químicas e microbiológicas para acompanhar o processo de maturação e a qualidade do produto final. A substituição parcial do $\mathrm{NaCl}$ por outros sais $\left(\mathrm{MgCl}_{2}, \mathrm{CaCl}_{2} \mathrm{KCl}\right)$ não interferiu no desenvolvimento da cultura starter do salame tipo italiano. A maioria dos parâmetros físico-químicos do salame italiano não foi alterada, bem como a qualidade microbiológica do produto final.

Palavras-chave: Embutido cárneo; Teor de sódio; Staphylococcus; Lactobacillus.

\section{Introduction}

Excessive salt consumption represents a risk to certain groups of sensitive individuals prone to altered blood pressure, cardiovascular diseases, diabetes and kidney disease.
Arterial hypertension affects more than $25 \%$ of the world's adult population, representing greater risk for cardiovascular disease (TOLDRÁ; REIG, 2011). Sodium ingestion must be 
restricted to less than $2,300 \mathrm{mg} /$ day for non-hypertensive individuals and to between $1,500 \mathrm{mg}$ and $2,300 \mathrm{mg} /$ day for hypertensive individuals (MAGALHÃES et al., 2010).

The addition of sodium chloride ( $\mathrm{NaCl}$ ) to fermented meats is critical to guarantee their microbiological stability, flavour and texture, and it contributes to their basic distinctive flavour (TERRA et al., 2004). Generally, quantities of 2.0 to $4.0 \%$ of $\mathrm{NaCl}$ are added, and these values increase in the final product due to the drying process. In addition to $\mathrm{NaCl}$, other salts, such as sodium nitrite $\left(\mathrm{NaNO}_{2}\right)$, sodium nitrate $\left(\mathrm{NaNO}_{3}\right)$ and sodium erythorbate $\left(\mathrm{C}_{6} \mathrm{H}_{7} \mathrm{NaO}_{6}\right)$ are added, which are used to accelerate the cure, as well as to improve the texture, develop the distinctive flavour and eliminate the reheated flavour and antimicrobial activity, and these are also sources of sodium (ZANARDI et al., 2010).

Alternatives have been tested in cooked meat products, both fresh and smoked, including mixtures of different salts such as $\mathrm{KCl}, \mathrm{CaCl}_{2}, \mathrm{MgCl}_{2}$ and potassium lactate (GIMENO et al., 2001; GELABERT et al., 2003; FULLADOSA et al., 2009; ARMENTEROS et al., 2009; VERMA et al., 2010; CARRARO et al., 2012; CIRIANO et al., 2013).

Starter cultures are used as a technological additive to manufacture fermented meat products, and are formed of numerous microbial species (IBAÑEZ et al., 1996). They are responsible for restricting the presence of undesirable microorganisms, reducing the manufacturing time, guaranteeing the homogeneity of the product, controlling the bacterial metabolism, improving the sensory characteristics and increasing the nutritional value, besides the ease of their technological applications (SHIMOKOMAKI et al., 2006). Several microbial species have been used in the preparation of fermented meat products with the purpose of providing the products with good sanitary quality (COELHO et al., 2009).

The salt concentration can affect the development of the starter culture and therefore the species selected for the preparation of fermented meat products must show good development under the processing conditions, including the temperature used and the presence of salt and nitrite (COELHO et al., 2009). Although the existing microorganisms reduce the nitrite concentration, the content of these compounds, together with the $\mathrm{NaCl}$ (both used in the curing salts), may affect the development of the starter cultures (HAULY et al., 2004).

Brazilian Normative no. 22 of July $31^{\text {st }}, 2000$, defines Italian salami as an industrialized meat product prepared with pork meat or a mixture of beef and pork meat, pork back fat, with the addition of additives and spices, ground to an average particle size between $6 \mathrm{~mm}$ and $9 \mathrm{~mm}$, filled into a natural or artificial casing, cured and smoked or otherwise (BRASIL, 2000).
In this study, we attempted to reduce the sodium content of Italian salami by partially replacing the $\mathrm{NaCl}$ by $\mathrm{KCl}, \mathrm{MgCl}_{2}$ and $\mathrm{CaCl}_{2}$, as well as verifying the impact on the counts of the Lactobacillus sp. and Staphylococcus $\mathrm{sp}$. cells found in the starter culture.

\section{Material and methods}

\subsection{Material}

Italian salami was prepared using the following ingredients: pork meat (boneless ham), beef (boneless sparerib) and pork back fat, salt (NaCl) (Diana, Curitiba, PR, Brazil), sucrose (crystal sugar), curing salt $(93.75 \% \mathrm{NaCl}$ and $6.25 \% \mathrm{NaNO}_{2}$ - Doremus Cura K001, Guarulhos, SP, Brazil), white pepper, garlic powder and nutmeg (local market), and sodium erythorbate (Doremus New Cor F014, Guarulhos, SP, Brazil).

The salts used were potassium chloride $(\mathrm{KCl})$ (Vetec, Duque de Caxias, RJ, Brazil), magnesium chloride $\left(\mathrm{MgCl}_{2}\right)$ (Nuclear, São Paulo, SP, Brazil) and calcium chloride $\left(\mathrm{CaCl}_{2}\right)$ (Vetec, Duque de Caxias, RJ, Brazil). The reagents used in the analysis were PA analytical grade.

The starter culture used was TEXEL ${ }^{\circledR} A S-308$ (Dupont Danisco, São Paulo, SP, Brazil) which contains the microorganisms Lactobacillus sakei, Staphylococcus carnosus and Staphylococcus xylosus with a total count of approximately $10.65 \mathrm{log}$ CFU.g ${ }^{-1}$.

\subsection{Preparation of the Italian salami}

Four formulations of Italian salami were prepared (Table 1). The proportion of raw material, sodium chloride, sugars and spices used was based on the formulation for Italian salami described by Terra (2005) and Terra et al. (2004), with the replacement of $60 \%$ of the sodium chloride. The starter culture was not added to formulation F1; the $\mathrm{NaCl}$ was partially replaced $(60 \%)$ by $\mathrm{KCl}$ in formulation $\mathrm{F} 3$ and by a mixture of $\mathrm{KCl}, \mathrm{MgCl}_{2}$ and $\mathrm{CaCl}_{2}$ in formulation $\mathrm{F} 4$.

Table 1. Formulations used in the manufacture of Italian salami.

\begin{tabular}{lcccc}
\multicolumn{1}{c}{ Ingredients } & F1 (\%) & F2 (\%) & F3 (\%) & F4 (\%) \\
Pork meat & 71 & 71 & 71 & 71 \\
Beef & 15 & 15 & 15 & 15 \\
Pork back fat & 10 & 10 & 10 & 10 \\
Sucrose & 0.3 & 0.3 & 0.3 & 0.3 \\
Curing salt & 0.3 & 0.3 & 0.3 & 0.3 \\
White pepper & 0.1 & 0.1 & 0.1 & 0.1 \\
Garlic powder & 0.1 & 0.1 & 0.1 & 0.1 \\
Ground nutmeg & 0.02 & 0.02 & 0.02 & 0.02 \\
Sodium erythorbate & 0.25 & 0.25 & 0.25 & 0.25 \\
Starter culture & - & 0.01 & 0.01 & 0.01 \\
$\mathrm{NaCl}_{\mathrm{KCl}}$ & 2.5 & 2.5 & 1 & 1 \\
$\mathrm{CaCl}_{2}$ & - & - & 1.5 & 0.5 \\
$\mathrm{MgCl}_{2}$ & - & - & - & 0.5 \\
\hline
\end{tabular}


The impact of the partial replacement of sodium chloride in the development of starter cultures during Italian salami production Fieira, C. et al.

The pork meat, beef and pork back fat were ground using an $8 \mathrm{~mm}$ disc. The ingredients were mixed manually, adding the salts first in order to extract the myofibrillar proteins. The starter culture was mixed with $50 \mathrm{ml}$ of distilled water, left to stand for 30 minutes and then added to the formulation. The others ingredients were added in sequence.

After mixing the mass was filled into collagen casings (40 mm).

The Italian salamis were stored in an industrial refrigerator at $7{ }^{\circ} \mathrm{C}$ for 12 hours, followed by smoking for 6 hours in an oven (Arprotec, Valinhos, SP, Brazil) at temperatures between $28{ }^{\circ} \mathrm{C}$ and $35{ }^{\circ} \mathrm{C}$, with a relative humidity of $85 \%$ and the injection of natural smoke. After curing, the salamis were incubated in a B.O.D. chamber (Logen, LS334, São Paulo, SP, Brazil), for 28 days (ripening period). The range of relative humidity was $75 \%$ to $95 \%$, and of temperature $18^{\circ} \mathrm{C}$ to $25^{\circ} \mathrm{C}$ according to the stage of ripening.

\subsection{Physicochemical analyses}

The physicochemical analyses of the formulations (F1, F2, F3 and F4) were carried out on days $0,3,7,14$, 21 and 28. All the evaluations were carried out in triplicate.

The $\mathrm{pH}$ value was determined to monitor the fermentation stage (TERRA et al., 2004) using a MS Tecpon instrument pH meter (mPA-210, Cachoeirinha, RS, Brazil). Gravimetric methods were used to evaluate the moisture content (IAL, 2008), and weight loss, by weighing a piece of sausage (MACEDO et al., 2008).

The moisture (gravimetric method), protein (Micro-Kjeldahl method), fat (Soxhlet) and ash (mineral residue by incineration) contents (IAL, 2008) were evaluated at the end of the maturation period of the salamis. The percent of carbohydrates was calculated as the difference between 100 and the sum of the protein, lipid, moisture, ash and chloride contents (BRASIL, 1998).

The water activity (Aw) of the samples was determined with the use of a water activity measurer at $25^{\circ} \mathrm{C}$ (Novasina, Lab Master, Lachen, Switzerland) and the percentage of chlorides was determined by the Mohr method (LANARA, 1981).

The instrumental colour was determined on the $28^{\text {th }}$ day of ripening, on the surface of the inner part of the samples. A colorimeter (KONICA MINOLTA CR 400/410, Osaka, Japan) was used to determine the CIELab coordinates: $L^{*}$ (luminosity or percent reflectance, ranging from black 0\% to white $100 \%$ ), $a^{*}$ (variation between the colours green $-a^{*}$ and red $+a^{*}$ ), and $b^{*}$ (variation between blue $-b^{*}$ and yellow $\left.+b^{*}\right)$, using illuminant D65 and an observation angle of $10^{\circ}$ (NASCIMENTO et al., 2007).

\subsection{Microbiological analyses}

The microbiological analyses were carried out on days $0,3,7,14,21$ and 28 . All evaluations were carried out in triplicate.

The Lactobacillus sp. count was done on MRS agar (Merck Chemicals, Darmstadt, Germany) and the Staphylococcus sp. count on Baird Parker agar (Himedia, Mumbai, India) with incubation at $37{ }^{\circ} \mathrm{C}$ for 48 hours. The results were expressed in CFU g ${ }^{-1}$ (MACEDO et al., 2008).

At the end of the maturation period, microbiological quality of the salamis was evaluated according to the requirements of Instruction RDC no. 12 (BRASIL, 2001), which requires the determinations of the fecal coliform and coagulase-positive Staphylococcus counts and the determination of the presence or absence of Salmonella $\mathrm{sp}$, all carried out according to the procedures described by Brasil (2003).

\subsection{Statistical analysis}

The data obtained in the analyses of the Italian salamis were subjected to the analysis of variance (ANOVA), and the means compared by Tukey's test, using a significance level of $5 \%(p<0.05)$ and the Statistica 7.0 software (StatSoft Inc., Tulsa, Oklahoma).

\section{Results and discussion}

\subsection{Evaluation of the salamis during the ripening stage}

\subsubsection{Lactobacillus sp. count}

The Lactobacillus sp. count (Table 2) was carried out to monitor the viable cells throughout the maturation process, verifying the impact of the replacement of $60 \%$ of the $\mathrm{NaCl}$ on the development of the starter culture.

Formulations F2 and F4 showed the highest number of viable Lactobacillus sp. cells on the day of manufacture (time 0) ( $p \leq 0.05)$. Aliño et al. (2009) did not find significant differences in the counts of aerobic mesophilic and lactic

Table 2. Lactobacillus sp. count (log CFU. $\left.\mathrm{g}^{-1}\right)$ in Italian salamis produced with different sodium contents during their ripening.

\begin{tabular}{ccccc}
$\begin{array}{c}\text { Time } \\
\text { (day) }\end{array}$ & F1 & F2 & F3 & F4 \\
0 & $3.04 \pm 0.05^{\mathrm{c}}$ & $6.01 \pm 0.00^{\mathrm{a}}$ & $5.89 \pm 0.01^{\mathrm{b}}$ & $6.02 \pm 0.02^{\mathrm{a}}$ \\
3 & $3.14 \pm 0.10^{\mathrm{c}}$ & $4.40 \pm 0.65^{\mathrm{b}}$ & $6.00 \pm 0.00^{\mathrm{a}}$ & $6.00 \pm 0.00^{\mathrm{a}}$ \\
7 & $3.56 \pm 0.17^{\mathrm{c}}$ & $5.64 \pm 0.04^{\mathrm{b}}$ & $5.54 \pm 0.06^{\mathrm{b}}$ & $6.00 \pm 0.00^{\mathrm{a}}$ \\
14 & $5.99 \pm 0.01^{\mathrm{a}}$ & $5.98 \pm 0.00^{\mathrm{a}}$ & $5.98 \pm 0.02^{\mathrm{a}}$ & $6.00 \pm 0.00^{\mathrm{a}}$ \\
21 & $3.99 \pm 0.00^{\mathrm{c}}$ & $5.82 \pm 0.03^{\mathrm{b}}$ & $5.99 \pm 0.01^{\mathrm{a}}$ & $6.00 \pm 0.00^{\mathrm{a}}$ \\
28 & $3.23 \pm 0.06^{\mathrm{d}}$ & $4.17 \pm 0.04^{\mathrm{c}}$ & $5.13 \pm 0.01^{\mathrm{a}}$ & $4.73 \pm 0.19^{\mathrm{b}}$ \\
\hline
\end{tabular}

Means \pm standard deviation; means followed by the same letter in the same line, do not represent a significant difference $(p \leq 0.05)$. F1: $\mathrm{NaCl}$; $\mathrm{F} 2: \mathrm{NaCl}+$ starter culture; $\mathrm{F} 3: \mathrm{NaCl}+\mathrm{KCl}+$ starter culture; $\mathrm{F} 4: \mathrm{NaCl}+\mathrm{KCl}+\mathrm{CaCl}_{2}+\mathrm{MgCl}_{2}+$ starter culture. 
acid bacteria amongst dry cured loin formulations with different salt concentrations However, Blesa et al. (2008) observed that the type of salt mixture used in the salting process might affect the viability of these bacteria in cured ham.

Formulation F4 (replacement of $60 \%$ of the $\mathrm{NaCl}$ by $\mathrm{KCl}, \mathrm{MgCl}_{2}$ and $\mathrm{CaCl}_{2}$ ) exhibited higher viable cell counts throughout the ripening period, although the number was lower than that in Formulation F3 (replacement of 60\% of the $\mathrm{NaCl}$ by $\mathrm{KCl}$ ) at the end of the process. Formulations $\mathrm{F} 1$ and F2 showed the lowest Lactobacillus sp. cell counts on the $28^{\text {th }}$ day. The partial replacement of sodium chloride ( $\mathrm{F} 3$ and $\mathrm{F} 4$ ) by $\mathrm{KCl}, \mathrm{MgCl}_{2}$ and $\mathrm{CaCl}_{2}$ did not affect the growth of Lactobacillus sp.

The Lactobacillus sp. counts in the Italian salamis corroborated the results obtained by Macedo et al. (2008), who verified that all the strains of Lactobacillus ( $L$. casei, L. paracaseissp. paracasei and L. caseissp. Rhamnosus) tested showed a high number of viable cells when cultured in MRS agar.

The results showed that the partial replacement of sodium chloride did not interfere with the activity of the Lactobacillus sp. This is desirable because the physiological activity of the microorganisms causes desirable transformations during the meat fermentation process, which influence the characteristics of the final product (SAWITZKI, 2007).

\subsubsection{Staphylococcus sp. count}

On the day of manufacture of the Italian salamis (time 0), the Staphylococcus sp. counts differed amongst the salami formulations $(p \leq 0.05)$ (Table 3$)$. Formulation F2 showed the highest count when compared to the other formulations, while formulation F4 exhibited the lowest Staphylococcus sp. count.

It is important to highlight that the formulations in which $60 \%$ of the $\mathrm{NaCl}$ was replaced by other salts, presented significantly ( $p \leq 0.05)$ lower Staphylococcus $\mathrm{sp}$ counts. The higher concentration of sodium chloride

Table 3. Staphylococcus sp. count (log CFU. $\left.g^{-1}\right)$ in Italian salamis produced with different sodium contents during ripening.

\begin{tabular}{ccccc}
$\begin{array}{c}\text { Time } \\
\text { (day) }\end{array}$ & F1 & F2 & F3 & F4 \\
\hline 0 & $5.66 \pm 0.05^{\mathrm{ab}}$ & $5.99 \pm 0.01^{\mathrm{a}}$ & $4.60 \pm 0.25^{\mathrm{c}}$ & $5.33 \pm 0.05^{\mathrm{b}}$ \\
3 & $4.38 \pm 0.35^{\mathrm{b}}$ & $5.10 \pm 0.11^{\mathrm{a}}$ & $5.15 \pm 0.12^{\mathrm{a}}$ & $4.67 \pm 0.15^{\mathrm{ab}}$ \\
7 & $6.00 \pm 0.00^{\mathrm{a}}$ & $6.00 \pm 0.00^{\mathrm{a}}$ & $5.98 \pm 0.02^{\mathrm{a}}$ & $5.81 \pm 0.05^{\mathrm{b}}$ \\
14 & $5.93 \pm 0.09^{\mathrm{a}}$ & $5.60 \pm 0.16^{\mathrm{b}}$ & $6.00 \pm 0.02^{\mathrm{a}}$ & $5.83 \pm 0.04^{\mathrm{ab}}$ \\
21 & $4.52 \pm 0.06^{\mathrm{b}}$ & $5.99 \pm 0.03^{\mathrm{a}}$ & $6.00 \pm 0.00^{\mathrm{a}}$ & $5.95 \pm 0.02^{\mathrm{a}}$ \\
28 & $5.81 \pm 0.02^{\mathrm{a}}$ & $5.33 \pm 0.03^{\mathrm{b}}$ & $6.00 \pm 0.00^{\mathrm{a}}$ & $4.54 \pm 0.23^{\mathrm{c}}$ \\
\hline
\end{tabular}

Means \pm standard deviation; averages followed by the same letter in the same line do not present a significant difference $(p \leq 0.05)$. $\mathrm{F} 1: \mathrm{NaCl} ; \mathrm{F} 2: \mathrm{NaCl}+$ starter culture; $\mathrm{F3}: \mathrm{NaCl}+\mathrm{KCl}+$ starter culture; $\mathrm{F} 4: \mathrm{NaCl}+\mathrm{KCl}+\mathrm{CaCl}_{2}+\mathrm{MgCl}_{2}+$ starter culture in formulation F2 might have improved the growth of Staphylococcus sp. These results are in agreement with Gonçalves (2013), who observed the tolerance of Staphylococcus carnosus to $\mathrm{NaCl}$ concentrations above $15 \%$ and the fact that Staphylococcus xylosus showed optimal growth in a culture medium containing $10 \% \mathrm{NaCl}$

Studies by Mauriello et al. (2004) and Casaburi et al. (2005) demonstrated that Staphylococcus carnosus and Staphylococcus simulans grew at temperatures of $15^{\circ} \mathrm{C}$ and $20^{\circ} \mathrm{C}$ (temperatures usually used for meat fermentation) in the presence of $10 \%, 15 \%$ or $20 \%$ of $\mathrm{NaCl}$, at $\mathrm{pH}$ values of 5.0 and 5.5. Gøtterup et al. (2007) also reported that S. xylosus showed optimum growth at $30^{\circ} \mathrm{C}, \mathrm{pH} 5.5$ with $20 \%$ of $\mathrm{NaCl}$.

At the end of the ripening process, formulation F3 showed the highest viable cell counts, exceeding the counts in formulation F2. This could be related to the lower $\mathrm{pH}$ values found in this formulation at the end of the maturation process. According to Gonçalves (2013), low $\mathrm{pH}$ values are adverse to the growth of Staphylococcus.

The presence of a high Lactobacillus sp. count in formulation F4 (Table 2) during maturation decreased the $\mathrm{pH}$ of the salami. This lower $\mathrm{pH}$ value probably caused the reduction in the number of Staphylococcus sp. since $\mathrm{pH}$ values below 5.7 adversely affect the development of this microorganism (STAHNKE, 1995). Papamanoli et al. (2003) and Macedo et al. (2008) working with fermented meats, also observed a drop in $\mathrm{pH}$, and related this to the high number of probiotic Lactobacillus cells.

The Staphylococcus sp. counts in formulation F3, with partial replacement of the $\mathrm{NaCl}$ by $\mathrm{KCl}$, were higher, demonstrating that the presence of this salt did not influence the development of the microorganism.

\subsection{3 $\mathrm{pH}$}

During the first 14 days of maturation the $\mathrm{pH}$ of the formulations varied from 4.99 to 5.51, and after this, from 4.98 to 5.8. According to Terra et al. (2004), lower $\mathrm{pH}$ values help the homo-fermentative lactic bacteria to exceed the contaminants due to competitive antagonism, besides providing the necessary conditions for the reduction of nitrate to nitrite in order to create nitrous myoglobin. In addition the drop in $\mathrm{pH}$ must occur gradually up to the seventh day, reaching values around 5.0, decreasing from the initial values of 5.8-6.0 to 5.0-5.2 in raw meats.

Formulation $\mathrm{F} 1$, with no starter culture, showed an initial $\mathrm{pH}$ of 5.54. This slowly decreased and then started to increase again after the $21^{\text {st }}$ day, finally reaching a $\mathrm{pH}$ of 5.64. Formulation F2, with starter culture, showed an initial $\mathrm{pH}$ of 5.81 which rapidly decreasing to 4.84 , subsequently increasing to 4.93 and finally reaching 5.65. The use of the starter culture allowed for faster acidification, avoiding the development of undesirable microorganisms, improving 
the colouration, speeding up dehydration and adding an acid flavour to the product (TERRA, 2005).

Formulations $\mathrm{F} 3$ and $\mathrm{F} 4$, with partial replacement of $60 \%$ of the sodium chloride, showed lower initial $\mathrm{pH}$ values in comparison with formulation F2 but also showed rapid acidification of the medium although sample F4 showed a lower final pH. Stahnke (1995) found a similar result in sausages with low sodium chloride contents ( $1 \%$ to $5 \%$ ), where the $\mathrm{pH}$ was reduced at high fermentation temperatures $\left(15^{\circ} \mathrm{C}\right.$ to $\left.25^{\circ} \mathrm{C}\right)$ and lower salt contents of.

The $\mathrm{pH}$ values found during the maturation period corroborated the results obtained by Campagnol et al. (2011), which can be considered normal for this type of meat product. Guardiá et al. (2008) replaced $50 \%$ of the $\mathrm{NaCl}$ by $\mathrm{KCl}$ in salamis and found no significant differences between the treatments.

\subsubsection{Weight loss and moisture}

The weight loss from salamis indicates the loss of water and also of important water-soluble substances during fermentation. Acidification occurs at this stage, and most of the water is released with proximity to the isoelectric point of the myofibrillar proteins. Dehydration is essential to the safety and quality of the product, also affecting other sensory characteristics (TERRA, 2005). Table 4 shows the average values obtained for weight loss and moisture content.

There was considerable weight loss during the maturation process of the Italian salamis, with a significant difference between treatments $(p \leq 0.05)$. The difference in weight loss between the $\mathrm{F} 2$ treatment, with starter culture, and the $\mathrm{F} 1$ treatment, without starter culture, was $3 \%$.
The replacement of $60 \%$ of the $\mathrm{NaCl}$ in treatments $\mathrm{F} 3$ and $\mathrm{F} 4$ caused increases of $7 \%$ and $5 \%$, respectively, in weight loss at the end of the process in relation to the F2 treatment. According to Sgarbiere (1998), this difference occurs because the addition of salt to meat products increases the ionic strength, improving the solubility and consequently the functionality of the myofibrillar proteins. Depending on the salt concentration of the medium, the meat proteins can either retain or release water.

There was a considerable variation in moisture content between treatments during the maturation process $(p \leq 0.05)$, treatments $F 4$ and $F 1$ showing the highest moisture losses. The replacement of $60 \%$ of the $\mathrm{NaCl}$ by $\mathrm{KCl}$ caused a $2 \%$ reduction in the moisture content and $6 \%$ reduction when replaced by the salt mixture at the end of the process. These results are in agreement with Guardiá et al. (2008), who observed a significant difference in the moisture content of salami when $50 \%$ of the $\mathrm{NaCl}$ was replaced by KCl, and with Aliño et al. (2009), when they replaced $70 \%$ of the $\mathrm{NaCl}$ by $\mathrm{KCl}$ in cured and dry loin.

\subsection{Characterization of the final product}

\subsubsection{Proximal composition, Aw and $\mathrm{pH}$}

The standards of identity and quality for Italian salamis determine the following product parameters: water activity of 0.90 ; maximum moisture content of $35 \%$; maximum fat content of $32 \%$; minimum protein content of $25 \%$; total carbohydrate content of $4 \%$ (BRASIL, 2000).

Table 5 shows the values obtained for the proximate composition, water activity and final $\mathrm{pH}$ of the salamis.

With regards to moisture content, only formulation F2 showed a value above that determined by the legislation (37\%).

Table 4. Weight loss and moisture content of Italian salamis produced with different sodium contents, during maturation (days).

\begin{tabular}{|c|c|c|c|c|c|c|c|c|}
\hline \multirow{2}{*}{$\begin{array}{l}\text { Time } \\
\text { (day) }\end{array}$} & \multicolumn{4}{|c|}{ Weight Loss (\%) } & \multicolumn{4}{|c|}{ Moisture content (\%) } \\
\hline & $\mathbf{F 1}$ & $\mathbf{F 2}$ & F3 & F4 & $\mathbf{F 1}$ & $\mathbf{F 2}$ & F3 & $\mathbf{F 4}$ \\
\hline 3 & $13 \pm 0.33^{a}$ & $10 \pm 0.47^{b}$ & $13 \pm 0.70^{a}$ & $13 \pm 0.49^{a}$ & NA & NA & NA & NA \\
\hline 7 & $13 \pm 0.33^{b}$ & $11 \pm 0.81^{c}$ & $16 \pm 1.40^{a}$ & $16 \pm 0.49^{a}$ & $85 \pm 0.57^{a}$ & $87 \pm 0.57^{a}$ & $75 \pm 0.57^{\circ}$ & $82 \pm 0.57^{b}$ \\
\hline 14 & $27 \pm 0.33^{c}$ & $25 \pm 0.81^{d}$ & $29 \pm 0.70^{b}$ & $32 \pm 0.49^{a}$ & $72 \pm 0.40^{b}$ & $75 \pm 0.40^{a}$ & $61 \pm 0.40^{d}$ & $68 \pm 0.40^{c}$ \\
\hline 21 & $37 \pm 0.33^{b}$ & $34 \pm 1.24^{b}$ & $41 \pm 0.70^{a}$ & $42 \pm 1.24^{\mathrm{a}}$ & $52 \pm 0.44^{b}$ & $57 \pm 0.44^{a}$ & $43 \pm 0.44^{c}$ & $51 \pm 0.44^{b}$ \\
\hline 28 & $44 \pm 0.33^{c}$ & $41 \pm 0.94^{d}$ & $48 \pm 0.70^{a}$ & $46 \pm 0.47^{b}$ & $34 \pm 1.28^{a b}$ & $37 \pm 1.28^{\mathrm{a}}$ & $35 \pm 1.28^{a b}$ & $31 \pm 1.28^{b}$ \\
\hline
\end{tabular}

Means \pm standard deviation; three repetitions; averages followed by the same letter in the same line do not show a significant difference ( $p \leq 0.05)$. F1: $\mathrm{NaCl}$; $\mathrm{F} 2: \mathrm{NaCl}+$ starter culture; $\mathrm{F} 3: \mathrm{NaCl}+\mathrm{KCl}+$ starter culture; $\mathrm{F} 4: \mathrm{NaCl}+\mathrm{KCl}+\mathrm{CaCl}_{2}+\mathrm{MgCl}_{2}+$ starter culture; $\mathrm{NA}=$ not evaluated.

Table 5. Moisture, ash, lipid, protein, chloride and carbohydrate contents (\%), and the Aw and pH values of Italian salamis produced with different sodium contents, after 28 days of ripening.

\begin{tabular}{ccccccccc} 
Formulation & Moisture & Ash & Lipid & Protein & Chloride & Carbohydrate & Aw & pH \\
F1 & $35.0 \pm 0.8^{\mathrm{ab}}$ & $7.0 \pm 0.0^{\mathrm{a}}$ & $13.5 \pm 0.1^{\mathrm{c}}$ & $30.6 \pm 0.3^{\mathrm{a}}$ & $5.3 \pm 0.1^{\mathrm{a}}$ & $8.3 \pm 0.6^{\mathrm{ab}}$ & $0.89 \pm 0.0^{\mathrm{a}}$ & $5.6 \pm 0.0^{\mathrm{a}}$ \\
F2 & $37.7 \pm 0.6^{\mathrm{a}}$ & $7.0 \pm 0.2^{\mathrm{a}}$ & $14.5 \pm 0.1^{\mathrm{b}}$ & $32.2 \pm 0.9^{\mathrm{a}}$ & $5.0 \pm 0.0^{\mathrm{a}}$ & $3.4 \pm 1.1^{\mathrm{bc}}$ & $0.89 \pm 0.0^{\mathrm{a}}$ & $5.6 \pm 0.0^{\mathrm{a}}$ \\
F3 & $35.3 \pm 1.1^{\mathrm{ab}}$ & $7.5 \pm 0.5^{\mathrm{a}}$ & $19.8 \pm 0.0^{\mathrm{a}}$ & $31.3 \pm 0.8^{\mathrm{a}}$ & $5.2 \pm 0.0^{\mathrm{a}}$ & $0.6 \pm 1.2^{\mathrm{c}}$ & $0.89 \pm 0.0^{\mathrm{a}}$ & $5.8 \pm 0.0^{\mathrm{a}}$ \\
F4 & $31.2 \pm 1.9^{\mathrm{b}}$ & $6.3 \pm 0.0^{\mathrm{a}}$ & $11.6 \pm 0.3^{\mathrm{d}}$ & $33.0 \pm 0.5^{\mathrm{a}}$ & $5.5 \pm 0.0^{\mathrm{a}}$ & $12.1 \pm 2.8^{\mathrm{a}}$ & $0.89 \pm 0.0^{\mathrm{a}}$ & $4.9 \pm 0.0^{\mathrm{b}}$ \\
\hline
\end{tabular}

Mean \pm standard deviation; three replicates; averages followed by the same letter in the same column do not show a significant difference ( $p \leq 0.05)$. F1: $\mathrm{NaCl} ; \mathrm{F} 2: \mathrm{NaCl}+$ starter culture; $\mathrm{F} 3: \mathrm{NaCl}+\mathrm{KCl}+$ starter culture; $\mathrm{F} 4: \mathrm{NaCl}+\mathrm{KCl}+\mathrm{CaCl}_{2}+\mathrm{MgCl}_{2}+$ starter culture. 
The impact of the partial replacement of sodium chloride in the development of starter cultures during Italian salami production Fieira, C. et al.

Table 6. Mean values for $L^{*}, a^{*}$ and $b^{*}$ in Italian salamis produced with different sodium contents, after 28 days of maturation.

\begin{tabular}{crrrr} 
Colour coordinate & F1 & F2 & F3 & F4 \\
$\mathbf{L}^{*}$ & $38.00 \pm 1.29^{\mathrm{b}}$ & $44.03 \pm 1.60^{\mathrm{ab}}$ & $44.32 \pm 2.85^{\mathrm{ab}}$ & $48.96 \pm 0.71^{\mathrm{a}}$ \\
$\mathbf{a}^{*}$ & $15.06 \pm 0.51^{\mathrm{a}}$ & $14.18 \pm 0.76^{\mathrm{a}}$ & $14.34 \pm 1.75^{\mathrm{a}}$ & $12.90 \pm 1.73^{\mathrm{a}}$ \\
$\mathbf{b}^{*}$ & $7.94 \pm 0.21^{\mathrm{a}}$ & $8.82 \pm 0.42^{\mathrm{a}}$ & $9.53 \pm 0.66^{\mathrm{a}}$ & $9.77 \pm 1.20^{\mathrm{a}}$ \\
\hline
\end{tabular}

Means \pm standard deviation; three repetitions; means followed by the same letter in the same line do not show a significant difference ( $p \leq 0.05)$. F1: $\mathrm{NaCl} ; \mathrm{F} 2: \mathrm{NaCl}+$ starter culture; $\mathrm{F} 3: \mathrm{NaCl}+\mathrm{KCl}+$ starter culture; $\mathrm{F} 4: \mathrm{NaCl}+\mathrm{KCl}+\mathrm{CaCl}_{2}+\mathrm{MgCl}_{2}+$ starter culture.

The quantities of ash and protein showed no significant differences ( $p \leq 0.05)$ between treatments. With respect to the lipid contents, all the formulations showed significant differences $(p \leq 0.05)$, but the protein contents of the four formulations were within the amounts allowed.

The Aw values obtained for the four formulations were close to the amounts required by the legislation. For the $\mathrm{pH}$ measurements, formulation F4 showed significantly different values $(p \leq 0.05)$ than the other formulations.

Formulation $\mathrm{F} 3$, with partial replacement of the $\mathrm{NaCl}$ by $\mathrm{KCl}$ showed lower values for the moisture, protein and carbohydrate contents and for Aw, and higher values for the ash and lipid contents and for $\mathrm{pH}$, in comparison with formulation F2. Formulation F4, in which the $\mathrm{NaCl}$ was partially replaced by a salt mixture, showed lower values for the moisture, ash and lipid contents and for $\mathrm{pH}$, and higher values for the protein and carbohydrate contents, in comparison to formulation F2.

Rech (2010) evaluated different formulations of Italian salami with reduced sodium contents and partial replacement with other salts. The author stated that variations in the chemical composition of the product occurred due to specific variables of the maturation process, such as the position of the stick and the position in the maturation chamber, amongst others.

Most of the physicochemical parameters of the Italian salami produced with reduced sodium content were not altered. Similar results were obtained by Vogel et al. (2011) in sausages, Gelabert et al. (2003) in fermented meats, Aliño et al. (2009) in cured dry lard, and Barbosa (2009) in Hamburg salami.

\subsubsection{Instrumental colour}

The treatments did not show significant differences $(p \leq 0.05)$ for the colour coordinates $a^{*}$ and $b^{*}$ at the end of ripening (Table 6 ). A similar result was found by Aliño et al. (2009), who found no significant differences ( $p 0.05)$ in the $a^{*}$ and $b^{*}$ values of cured and dry loin with the replacement of $35 \%, 50 \%$ and $70 \%$ of $\mathrm{NaCl}$ by $\mathrm{KCl}$.

The luminosity values were higher in formulation F4. According to Aliño et al. (2010), higher calcium and magnesium contents, and differences in the water content, $\mathrm{pH}$ and additives can cause alterations in the luminosity $\left(\mathrm{L}^{*}\right)$.

\subsubsection{Microbiological characterization of the final product}

In order to evaluate the microbiological quality of the treatments after 28 days, the following analyses were performed: fecal coliforms, positive coagulase Staphylococcus, and Salmonella sp. According to the Brazilian legislation (Brasil, 2001), the maximum limit for the count of fecal coliforms, positive coagulase Staphylococcus and Salmonella sp. in fermented meats are $10^{3} \mathrm{CFU} / \mathrm{g}, 5 \times 10^{3}$ in CFU/g and absence in $25 \mathrm{~g}$ of the product. Regarding these standards, salami of all treatments met the Legislation requirements.

\section{Conclusion}

The partial replacement of $\mathrm{NaCl}$ by other salts $\left(\mathrm{MgCl}_{2}, \mathrm{CaCl}_{2}, \mathrm{KCl}\right)$ did not interfere in the growth of the starter culture in Italian salami. The growth of Lactobacillus $\mathrm{sp}$. was improved by the partial replacement of $\mathrm{NaCl}$ by $\mathrm{MgCl}_{2}, \mathrm{CaCl}_{2}$ or $\mathrm{KCl}$. The partial replacement of $\mathrm{NaCl}$ did not affect most of the physicochemical parameters of the Italian salami or the microbiological quality of the final product.

\section{References}

ALIÑO, M.; GRAU, R.; TOLDRÁ, F.; BARAT, J. M. Physicochemical changes in dry-cured hams salted with potassium, calcium and magnesium chloride as a partial replacement for sodium chloride. Meat Science, v. 86, n. 2, p. 331-336, 2010. PMid:20541872. http://dx.doi.org/10.1016/j.meatsci.2010.05.003.

ALIÑO, M.; GRAU, R.; TOLDRÁ, F.; BLESA, E.; PAGÁN, M. J.; BARAT, J. M. Influence of sodium replacement on physicochemical properties of dry-cured loin. Meat Science, v. 83, n. 3, p. 423-430, 2009. PMid:20416693. http://dx.doi.org/10.1016/j. meatsci.2009.06.022.

ARMENTEROS, M.; ARISTOY, M. C.; BARAT, J. M.; TOLDRÁ, $F$. Biochemical changes in dry-cured loins salted with partial replacements of $\mathrm{NaCl}$ by $\mathrm{KCl}$. Food Chemistry, v. 117, n. 4, p. 627-633, 2009. http://dx.doi.org/10.1016/j.foodchem.2009.04.056.

BARBOSA, R. G. Fabricação de salame tipo hamburguês com substituição parcial de sódio. 2009. 70 f. Dissertação (Mestrado em Ciência e Tecnologia dos Alimentos)-Universidade Federal de Santa Maria, Santa Maria, 2009.

BLESA, E.; ALIÑO, M.; BARAT, J. M.; GRAU, R.; TOLDRÁ, F.; PAGÁN, M. J. Microbiology and physico-chemical changes of dry-cured ham during the post salting stage as affected by partial 
The impact of the partial replacement of sodium chloride in the development of starter cultures during Italian salami production Fieira, C. et al.

replacement of $\mathrm{NaCl}$ by other salts. Meat Science, v. 78, n. 1-2, p. 135-142, 2008. PMid:22062103. http://dx.doi.org/10.1016/j. meatsci.2007.07.008.

BRASIL. Ministério da Saúde. Secretaria de Vigilância Sanitária. Portaria $n^{\circ} 27$, de 13 de janeiro de 1998. Regulamento técnico referente à informação nutricional complementar (declarações relacionadas ao conteúdo de nutrientes). Diário Oficial [da] República Federativa do Brasil, Brasília, DF, 16 jan. 1998.

BRASIL. Ministério da Agricultura e do Abastecimento. Secretaria de Defesa Agropecuária. Instrução normativa n²2, de 31 de julho de 2000. Anexo XII. Regulamento técnico de identidade de qualidade de salame tipo italiano. Diário Oficial [da] República Federativa do Brasil, Brasília, DF, 1 ago. 2000.

BRASIL. Ministério da Saúde. Agência Nacional de Vigilância Sanitária - ANVISA. Resolução RDC n 12, de 2 de janeiro de 2001. Aprova o regulamento técnico de padrões microbiológicos sanitários para alimentos (Grupo 5l). Diário Oficial [da] República Federativa do Brasil, Brasília, DF, 10 jan. 2001.

BRASIL. Ministério da Agricultura e do Abastecimento. Secretaria de Defesa Agropecuária. Instrução normativa n 62 de 26 de agosto de 2003. Oficializa os métodos analíticos oficiais para análises microbiológicas para controle de produtos de origem animal e água. Diário Oficial [da] República Federativa do Brasil, Brasília, DF, 18 set. 2003.

CAMPAGNOL, P. C. B.; SANTOS, B. A.; MORGANO, M. A.; TERRA, N. N.; POLLONIO, M. A. R. Application of lysine, taurine, disodium inosinate and disodium guanylate in fermented cooked sausages with $50 \%$ replacement of $\mathrm{NaCl}$ by $\mathrm{KCl}$. Meat Science, v. 87 , n. 3, p. 239-243, 2011. PMid:21067870. http://dx.doi. org/10.1016/j.meatsci.2010.10.018.

CARRARO, C. I.; MACHADO, R.; ESPINDOLA, V.; CAMPAGNOL, P. C. B.; POLLONIO, M. A. P. The effect of sodium reduction and the use of herbs and spices on the quality and safety of Bologna sausage. Ciência e Tecnologia de Alimentos, v. 32, n. 2, p. 289-297, 2012. http://dx.doi.org/10.1590/S010120612012005000051.

CASABURI, A.; BLAIOTTA, G.; MAURIELLO, G.; PEPE, O.; VILLANI, F. Technological activities of Staphylococcus carnosus and Staphylococcus simulans strains isolated from fermented sausages. Meat Science, v. 71, n. 4, p. 643-650, 2005. PMid:22061209. http://dx.doi.org/10.1016/j.meatsci.2005.05.008.

CIRIANO, M. G. I.; BERASATEGI, I.; NAVARRO-BLASCO, I.; ASTIASARAN, I.; ANSORENA, D. Reduction of sodium and increment of calcium and omega-3 polyunsaturated fatty acids in dry fermented sausages: effects on the mineral content, lipid profile and sensory quality. Journal of the Science of Food and Agriculture, v. 93, n. 4, p. 876-881, 2013. PMid:22865242. http://dx.doi.org/10.1002/jsfa.5811.

COELHO, M. S.; BENEVENUTO, W. C. A. N.; BENEVENUTO JUNIOR, A. A.; CARLOS, F. G. Efeito de culturas láticas selecionadas na elaboração de salame tipo italiano. In: SEMANA DE CIÊNCIA E
TECNOLOGIA DO IFMG CAMPUS BAMBUII, JORNADA CIENTÍFICA, 2., 2009, Bambuí. Anais... Bambuí: IFMG, 2009. p. 1-5.

FULLADOSA, E.; SERRA, X.; GOU, P.; ARNAU, J. Effects of potassium lactate and high pressure on transglutaminase restructured dry-cured hams with reduced salt content. Meat Science, v. 82, n. 2, p. 213-218, 2009. PMid:20416756. http:// dx.doi.org/10.1016/j.meatsci.2009.01.013.

GELABERT, J.; GOU, P.; GUERRERO, L.; ARNAU, J. Effect of sodium chloride replacement on some characteristics of fermented sausages. Meat Science, v. 65, n. 2, p. 833-839, 2003. PMid:22063446. http://dx.doi.org/10.1016/S0309-1740(02)00288-7.

GIMENO, O.; ASTIASARÁN, I.; BELLO, J. Calcium ascorbate as a potential partial substitute for $\mathrm{NaCl}$ in dry fermented sausages: effect on colour, texture, and higienic quality at different concentrations. Meat Science, v. 57, n. 1, p. 23-29, 2001. PMid:22061163. http:// dx.doi.org/10.1016/S0309-1740(00)00070-X.

GONÇALVES, E. S. Influência do sal, pH e temperatura no desenvolvimento de Estafilococos Coagulase Negativa isolados de produtos cárneos fermentados. 2013. 57 f. Dissertação (Mestrado)-Faculdade de Medicina Veterinária, Universidade de Lisboa, Lisboa, 2013.

GØTTERUP, J.; OLSEN, K.; KNÖCHEL, S.; TJENER, K.; STAHNKE, L. H.; MØLLER, J. K. S. Relationship between nitrate/nitrite reductase activities in meat associated staphylococci and nitrosylmyoglobin formation in a cured meat model system. International Journal of Food Microbiology, v. 120, n. 3, p. 303-310, 2007. PMid:17920151. http://dx.doi.org/10.1016/j. ijfoodmicro.2007.08.034.

GUARDIÁ, M. D.; GUERRERO, L.; GELABERT, J.; GOU, P.; ARNAU, J. Sensory characterisation and consumer acceptability of small calibre fermented sausages with $50 \%$ substitution of $\mathrm{NaCl}$ by mixtures of $\mathrm{KCl}$ and potassium lactate. Meat Science, v. 80, n. 4, p. 1225-1230, 2008. PMid:22063862. http://dx.doi. org/10.1016/j.meatsci.2008.05.031.

HAULY, M. C. O.; NOGUEIRA, R. B.; OLIVEIRA, A. S. Influência do $\mathrm{NaCl}$ e do $\mathrm{NaNO}_{2}$ sobre a fermentação lática desenvolvida pelo Lactobacillus curvatus em meio MRS. Semina: Ciências Exatas e Tecnológicas, v. 22, n. 1, p. 37-41, 2004. http://dx. doi. org/10.5433/1679-0375.2001v22n1p37.

IBAÑEZ, C.; QUINTANILLA, L.; CID, C.; ASTIASARAN, I.; BELLO, J. Dry fermented sausages elaborated with Lactobacillus plantarumStaphylococcus carnosus part I: effect of partial replacement of $\mathrm{NaCl}$ with $\mathrm{KCl}$ on the stability and the nitrosation process. Meat Science, v. 44, n. 4, p. 227-234, 1996. PMid:22060939. http:// dx.doi.org/10.1016/S0309-1740(96)00035-6.

INSTITUTO ADOLFO LUTZ - IAL. Métodos físico-químicos para análise de alimentos. 4. ed. São Paulo: IAL, 2008. 1020 p.

LANARA, M. Métodos analíticos oficiais para controle de produtos de origem animal e seus ingredientes. Brasília: Ministério da Agricultura, 1981. 123 p. 
The impact of the partial replacement of sodium chloride in the development of starter cultures during Italian salami production Fieira, C. et al.

MACEDO, R. E. F.; PFLANZER JUNIOR, S. B.; TERRA, N. N.; FREITAS, R. J. S. Desenvolvimento de embutido fermentado por Lactobacillus probióticos: características de qualidade. Ciência e Tecnologia de Alimentos, v. 28, n. 3, p. 509-519, 2008. http:// dx.doi.org/10.1590/S0101-20612008000300002.

MAGALHÃES, M. E. C.; BRANDÃO, A. A.; POZZAN, R.; CAMPANA, E. M. G.; FONSECA, F. L.; PIZZI, O. L.; BRANDÃO, A. P. Prevenção da hipertensão arterial: para quem e quando começar? Revista Brasileira Hipertensão, v. 17, n. 2, p. 93-97, 2010.

MAURIELLO, G.; CASABURI, A.; BLAIOTTA, G.; VILLANI, F. Isolation and technological properties of coagulase negative staphylococci from fermented sausages of Southern Italy. Meat Science, v. 67, n. 1, p. 149-158, 2004. PMid:22061128. http:// dx.doi.org/10.1016/j.meatsci.2003.10.003.

NASCIMENTO, R.; CAMPAGNOL, P. C. B.; MONTEIRO, E. S.; POLLONIO, M. A. R. Substituição de cloreto de sódio por cloreto de potássio: influência sobre as características físico-químicas e sensoriais de salsichas. Alimentos e Nutrição, v. 18, n. 3, p. 297-302, 2007.

PAPAMANOLI, E.; TZANETAKIS, N.; LITOPOULOU-TZANETAKI, E.; KOTZEKIDOU, P. Characterization of lactic acid bactéria isolated from a Greek dry-fermented sausage in respect of their technological and probiotic properties. Meat Science, v. 65, n. 2, p. 859-867, 2003. PMid:22063449. http://dx.doi.org/10.1016/ S0309-1740(02)00292-9.

$\mathrm{RECH}, \mathrm{R}$. A. Produção salame tipo italiano com teor de sódio reduzido. 2010. 70 f. Dissertação (Mestrado em Ciência e Tecnologia dos Alimentos)-Centro de Ciências Rurais, Universidade Federal de Santa Maria, Santa Maria, 2010.

SAWITZKI, M. C. Propriedades tecnológicas de Lactobacillus plantarum isolado de salames artesanais e aplicado como cultivo iniciador em salame tipo milano. 2007. 97 f. Tese (Doutorado em Ciência de Alimentos)-Universidade Federal de Santa Catarina, Florianópolis, 2007.
SGARBIERE, V. C. Propriedades funcionais de proteínas em alimentos. Boletim SBCTA, v. 32, n. 1, p. 105-126, 1998.

SHIMOKOMAKI, M.; OLIVO, R.; TERRA, N. N.; FRANCO, B. D. G. M. Atualidades em ciência e tecnologia de carnes. São Paulo: Livraria Varela, 2006. 236 p.

STAHNKE, L. H. Dried sausages fermented with Staphylococcus xylosusat different temperatures and with different ingredient levels. Part I: chemical and bacteriological data. Meat Science, v. 41, n. 2, p. 179-191, 1995. PMid:22060168. http://dx.doi. org/10.1016/0309-1740(94)00070-N.

TERRA, A. B. M.; FRIES, L. L. M.; TERRA, N. N. Particularidades na fabricação de salame. São Paulo: Livraria Varela, 2004. 152 p.

TERRA, N. N. Apontamentos sobre tecnologia de carnes. São Leopoldo: Editora UNISINOS, 2005. 216 p.

TOLDRÁ, F.; REIG, M. Innovations for healthier processed meats. Trends in Food Science \& Technology, v. 22, n. 9, p. 517-522, 2011. http://dx.doi.org/10.1016/j.tifs.2011.08.007.

VERMA, A. K.; SHARMA, B. D.; BANERJEE, R. Effect of sodium chloride replacement and apple pulp inclusion on the physicochemical, textural and sensory properties of low fat chicken nuggets. Lebensmittel-Wissenschaft + Technologie, v. 43, n. 4, p. 715-719, 2010. http://dx.doi.org/10.1016/j.Iwt.2009.12.006. VOGEL, C. C.; PAZUCH, C. M.; SARMENTO, C. M. P.; BACK, L.; SECCO, T. H. Desenvolvimento de salsicha com teor de sódio reduzido (sal light). Revista Ciências Exatas e Naturais, v. 13, n. 3, p. 305-316, 2011.

ZANARDI, E.; GHIDINI, S.; CONTER, M.; IANIERI, A. Mineral composition of Italian salami and effect of $\mathrm{NaCl}$ partial replacement on compositional, physico-chemical and sensory parameters. Meat Science, v. 86, n. 3, p. 742-747, 2010. PMid:20663614. http://dx.doi.org/10.1016/j.meatsci.2010.06.015. 